\title{
Deterioration of sunflower seeds during storage ${ }^{1}$
}

\author{
Luciana Aparecida de Souza Abreu², Maria Laene Moreira de Carvalho², \\ Crislaine Aparecida Gomes Pinto², Verônica Yumi Kataoka³, \\ Tanismare Tatiana de Almeida Silva ${ }^{2}$
}

\begin{abstract}
The speed on deterioration of oil-seeds depends on conditions of the storage environment and on particularities of the species, which include the seed chemical composition. Within this study, the changes on quality of sunflower seeds, stored in different packaging types and environmental conditions, were investigated. The packaging used were multiwall Kraft paper and plastic packaging (with and without vacuum), under cold chamber and conventional storage conditions. Seed quality was evaluated by tests of: germination and accelerated aging; besides alterations on oil content, fatty acids profile, and isoenzymatic systems. The storage under cold chamber conditions was more efficient in maintaining physiological quality of sunflower seeds; and under such environment, the Kraft paper packaging was the most adequate. Under conventional storage facility, however, the plastic packaging, sealed with vacuum, has provided better maintenance of physiological quality. Changes in the sunflower seed quality were detected by the enzymatic systems: alcohol dehydrogenase and superoxide dismutase. The oil content in seeds decreases over time, regardless of storage condition. The linoleic and oleic acids constituted $80 \%$ of the total amount of fatty acids scanned. There have been no significant differences on the fatty acid profiles of the sunflower oil under the different storage conditions studied.
\end{abstract}

Index terms: Helianthus annuus, oil-seeds, chemical composition, conservation.

\section{Deterioração de sementes de girassol durante o armazenamento}

\begin{abstract}
RESUMO - A velocidade de deterioração de sementes oleaginosas depende das condições do ambiente de armazenamento e das particularidades da espécie, que incluem a composição química dessas sementes. Neste trabalho, foram investigadas as alterações na qualidade de sementes de girassol armazenadas em diferentes tipos de embalagens e ambientes. As embalagens foram papel Kraft multifoliado e embalagem plástica (com e sem vácuo) sob condições de câmara fria e armazém convencional. A qualidade das sementes foi avaliada pelos testes de: germinação e envelhecimento acelerado; além de alterações no teor de óleo, perfil de ácidos graxos e sistemas isoenzimáticos. O armazenamento em câmara fria foi mais eficiente na conservação da qualidade das sementes de girassol e, nesse ambiente, a embalagem de papel foi mais adequada. Entretanto, em armazém convencional a embalagem plástica, fechada a vácuo, propiciou melhor manutenção da qualidade fisiológica. Alterações na qualidade fisiológica de sementes girassol foram detectadas pelos sistemas enzimáticos: álcool desidrogenase e superóxido dismutase. O teor de óleo nas sementes decresce ao longo do tempo, independente da condição de armazenamento. Os ácidos linoleico e oleico perfizeram $80 \%$ do total dos ácidos graxos verificados. Não houve diferenças significativas no perfil dos ácidos graxos no óleo de girassol nas diferentes condições de armazenamento.
\end{abstract}

Termos para indexação: Helianthus annuus, semente oleaginosa, composição química, conservação.

\section{Introduction}

The cultivation of sunflower (Helianthus annuus L.) has significantly increased in recent years, mainly due to quality of its oil, which is useful for the human consumption and for production of biodiesel. In addition, due to its large capacity

${ }^{1}$ Submitted on 11/07/2012. Accepted for publication on 12/07/2012.

${ }^{2}$ Departamento de Agricultura, Universidade Federal Lavras, Caixa Postal 3037, 37200-000 - Lavras, MG, Brasil. of adaptation to different edaphic-climatic conditions, sunflower is an excellent option for crop rotation and succession systems for several production regions (Carvalho et al., 2003). However, for that the supply of this raw- material could be successfully increased, there is still the need for production of seeds of high quality as well as the broadening 
of knowledge on storage and conservation of its seeds. To reach this level, however, this crop has to be capable of facing other oil-seed options, whose technologies, for production and storage conditions, have already been improved and/or are more refined.

Among the factors affecting seed quality during storage: the initial quality of the seed lot; the environment for conservation (with its variations on temperature, moisture, oxygen availability; and the packaging) as well as characteristics inherent to the species, should be taken into account. The type of packaging during storage, assumes relevant importance on seed quality, once the packaging indeed helps on lessening the speed of deterioration, by maintaining the initial moisture content of seeds stored, and by diminishing, or not, their respiration rate (Tonin and Perez, 2006).

The moisture content and the temperature of seed storage can be easily manipulated during the storage process within an environment in which it is possible to control such factors (chambers with environmental control). By its turn, the content of available oxygen may be reduced by the procedure of packaging into vacuum sealed impermeable plastic bags, or by injection of an oxygen-free gas. Schmidt (2007) demonstrated that seeds of tropical forestal species, maintained into a low oxygen concentrations environment, diminish their deterioration and aging processes. In studies performed with sweet corn, Camargo and Carvalho (2008) have proved the efficiency in using vacuum sealed impermeable packaging in preserving seed quality, under conventional storage conditions. However, such type of packaging may result in non significant gains; therefore, not actually justifying its wide use.

The peroxidation of lipids may be the most frequent cause of deterioration and loss of viability of seeds, since it is a factor that leads to reduction on content of lipids in seeds during the storage procedure. Many times, such factor may be activated by the action of oxygen on a given polyunsaturated fatty acid, which is present in the membranes of seeds. In addition, in the process of seed deterioration, the increase on peroxidation of lipids results in damages to the cell membrane, and consequent generation of toxic sub-products (Schwember and Bradford, 2010). Enzymatic changes may seem to be also useful in studies on seed deterioration. Thus, the decrease of antioxidant enzymes is linked to increase on peroxidation of lipids as well as to accelerated aging process, with a positive correlation between antioxidant capacity of the enzyme and the vigor of seeds (Bailly et al., 2002).

The content of oil in seeds may vary according to plant genotype and the storage conditions, especially temperature and relative humidity (Koutroubas et al., 2000) and such variations directly influence degradation of the oil during storage. For Walters et al. (2010), the chemical degradation of seed components during storage occurs through damages caused by oxidant agents, but the speed of such reactions is defined by properties of the seeds, which by their turn are affected by temperature as well as by moisture.

A thorough evaluation of oil from seeds of sunflower, which were stored under different conditions, may elucidate some uncertainties related to deterioration process of this species seeds. For Lehner et al. (2006) the physical characteristics of the reserves of lipids on sunflower cotyledons are regulated during their development and can affect the germination and conservation of the seeds. Considering that studies related to ideal conditions of storage of sunflower seeds are still scarce; as well as still is little the amount of information concerning physiological quality of such seeds under different storage conditions; it is desirable that the knowledge on the potentialities of this species are studied during all the period in which these seeds are to be stored.

This research work was aimed at investigating the effect of different types of packaging and different storage conditions on the quality of sunflower seeds, during 12 months, in relation to physiological and biochemical changes that might have occurred in those seeds.

\section{Material and Methods}

The research work was carried out at the Central Laboratory of Seeds; Federal University of Lavras (UFLA), Lavras, State of Minas Gerais, Brazil; from May 2008 to May 2009. In the experiment were used sunflower seeds of two hybrids: Helio 250 (high oil content) and Helio 251 (low oil content), produced by the Helianthus do Brasil Ltda. (Helianthus of Brazil Ltd.) stored under two environmental conditions: cold and dry chamber (constant temperature of $10{ }^{\circ} \mathrm{C}$; and $40 \% \mathrm{RH}$ ); and conventional storage facility (temperatures varying between $18{ }^{\circ} \mathrm{C}$ and $20{ }^{\circ} \mathrm{C}$; and $\mathrm{RH}$ varying from $50 \%$ to $70 \%$ ). The seeds were stored into two type of packaging: multiwall Kraft paper $(25 \mathrm{~cm}$ x $15 \mathrm{~cm})$; and transparent polyethylene bags ( $25 \mathrm{~cm}$ x $15 \mathrm{~cm} \times 0.12 \mu$ thick); this last type of packaging was used with and without vacuum. At each four months period, within a total period of 12 month storage, the quality of sunflower seeds was assessed by the following methods:

Germination test: was performed with four replications of 50 seeds each, for each treatment. The substrate used was three sheets of paper towels containing the seeds, which after being moistened with distilled water, equivalent to 2.5 times the mass of the dry substrate, were made into rolls and kept into seed germinator, at $25{ }^{\circ} \mathrm{C}$. The counts were performed at the fourth and the tenth day after sowing (Brasil, 2009); and results were expressed in percentage of normal seedlings.

Accelerated aging: was performed with four replications of 50 seeds each, for each treatment. For such, the seeds 
were evenly distributed in a single layer onto an aluminum screen, adapted to the upper edge of $11 \mathrm{~cm} \mathrm{x} 11 \mathrm{~cm} \times 3.5 \mathrm{~cm}$ in dimensions germination boxes (Gerbox). Afterwards, each gerbox, in which a $40 \mathrm{~mL}$ aliquot of distilled water had already been previously placed at the bottom, were immediately kept into BOD type chambers, at $42^{\circ} \mathrm{C}$, for $48 \mathrm{~h}$. After such period, the seeds were subjected to germination test, according to Brasil (2009).

Oil content: extraction and quantification of oil present in seeds were performed with $100 \mathrm{~g}$ samples of sunflower seeds, from each replication and treatment, which after the drying procedure were ground and placed into evaporation flasks, with $500 \mathrm{~mL}$ capacity each. Into each flask, $200 \mathrm{~mL}$ hexane was then added, and the solution was brought to reflux. After $24 \mathrm{~h}$, the solution was filtered, discarding the solid portion, and supernatant was brought to evaporation into a rotaryevaporator, Buchi-144 brand, under reduced pressure. The so obtained oil from each sample was placed into an oven at $35{ }^{\circ} \mathrm{C}$, during $24 \mathrm{~h}$, for complete solvent evaporation and subsequent weighing. Results were expressed in grams of oil per gram of dried and ground seed.

Profile of fatty acids by gas chromatography: for chromatographic analysis of fatty acids a gas chromatographer, Variant brand (Walnut Creek, USA), model GC 3900, equipped with a flame-ionization detector, injector, and automatic sampler was used. The compounds were separated in a CP-Sil 88 fused-silica capillary column, $50 \mathrm{~cm}$ long, internal diameter of $0.25 \mathrm{~mm}$, and film thickness of $0.20 \mu \mathrm{m}$. The column temperature program was initiated at $50{ }^{\circ} \mathrm{C}$, for $2 \mathrm{~min}$., heated in $4{ }^{\circ} \mathrm{C}$ per minute, until reaching $240{ }^{\circ} \mathrm{C}$, and then maintained in isotherm during $20 \mathrm{~min} .: 05$ sec. The temperatures used in the injector and in the detector were $230{ }^{\circ} \mathrm{C}$ and $250{ }^{\circ} \mathrm{C}$, respectively. The samples were injected in volumes of $1 \mu \mathrm{L}$, adopting the splitter ratio of 01:30. The drag gas used was hydrogen, with linear speed of $30 \mathrm{~mL} . \mathrm{min} .^{-1}$. The fatty acids were identified by comparing the standards of retention time of pure methyl esters of fatty acids with the components separated from samples; and the quantification was performed by area normalization (\%). As patterns, a mixture of 37 methyl esters of fatty acids (Supelco, Bellefonte, USA), from C 4:0 to C $24: 1$, with purity between $99.1 \%$ e $99.9 \%$ was used.

Isoenzymes analyses: at each interval of four months, samples of $100 \mathrm{~g}$ of seeds were removed from each treatment to perform electrophoresis of enzymes. The seed samples were ground on ice, into a mortar, with Polyvinylpyrrolidone (PVP) and liquid nitrogen and afterwards stored at temperature of $-86{ }^{\circ} \mathrm{C}$. For extraction of enzymes, a $0.2 \mathrm{M}$ Tris $\mathrm{HCl}$ buffer, $\mathrm{pH} 8.0+0.1 \% \beta$ mercaptoethanol was used, in a ratio of
$250 \mu \mathrm{L} .100 \mathrm{mg}$ of seeds ${ }^{-1}$. The material was then homogenized onto a Vortex shaker, and maintained overnight into a common refrigerator, followed by centrifuging at $14,000 \mathrm{rpm}$, for $30 \mathrm{~min}$., at $4{ }^{\circ} \mathrm{C}$. The electrophoretic runs were performed in polyacrylamide gels systems (7.5\% separator gel; $4.5 \%$ concentrator gel). The gel/ electrode system used was the Tris-Glycine, $\mathrm{pH}$ 8.9. For this, 50 $\mu \mathrm{L}$ of supernatant of the samples were applied to the gels and the run was performed at $150 \mathrm{~V}$ during $4 \mathrm{~h}$. After the run, the gels were stained for the enzymes superoxide dismutase (SOD), alcohol dehydrogenase $(\mathrm{ADH})$, and malate dehydrogenase (MDH), according to Alfenas et al. (1998).

Experimental design: for the experiment it was used a completely randomized experimental design, with four replications, with treatments arranged in a $4 \times 3 \times 2$ factorial scheme $\{4$ evaluation periods $(0,4,8$ and 12 months $) \times 3$ packaging methods (multiwall Kraft paper bags, transparent plastic bags and vacuum sealed transparent plastic bags) x 2 storage environments (cold chamber and conventional storage facilities) $\}$. For results obtained in the tests on germination and oil content, regression analyses were performed separately for each sunflower hybrid.

\section{Results and Discussion}

By analyzing germination of seeds of hybrids Helio 250 and Helio 251, starting from the fourth month of storage (Figure 1) a trend of reduction on seed quality over time is evident; independent of storage conditions. Such results come to prove those obtained by Grisi and Santos (2007), who have concluded that the physiological quality of sunflower seeds, belonging to the same genotypes used in this study, were negatively affected by the advance in time of storage, for both conventional storage facilities or cold chamber conditions, what demonstrates susceptibility of those seeds to deterioration within a short term period.

In a general way, the storage under cold chamber condition in relation to the conventional storage has provided better preservation of sunflower seeds physiological quality. For both hybrids, the seeds stored into cold chamber have had higher mean percent of germination when packaged into multiwall Kraft paper bags. According to Cavasin (2001), for storage of sunflower seeds, the use of cold chamber (with temperatures between $10{ }^{\circ} \mathrm{C}$ and $15^{\circ} \mathrm{C}$ ), into paper bags, is indeed recommended.

Within this study, best results for germination were found for seeds of hybrid Helio 250, stored under conventional storage facility and packaged into plastic bags, with or without oxygen restriction, in relation to seeds packaged into multiwall paper bags. In the eighth month, the superiority of 
germination of seeds packaged with vacuum into plastic bags and stored without control of the environmental temperature was highlighted. The storage of vacuum packaged seeds, under temperatures close to $25^{\circ} \mathrm{C}$, have provided the best preservation for seeds; and the oxygen restriction in the vacuum packages, associated to low storage temperatures have drastically reduced the physiological quality of seeds. Therefore, the response to storage of sunflower seeds into cold chamber or conventional storage facilities varied much more in function of type of packaging used.

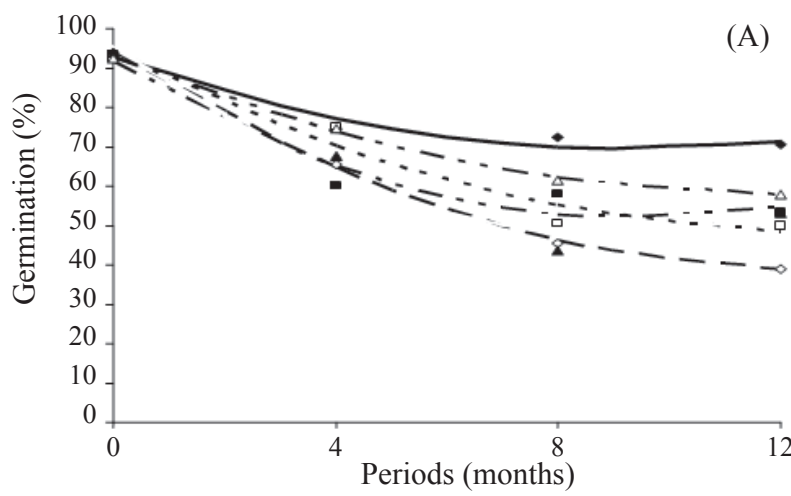

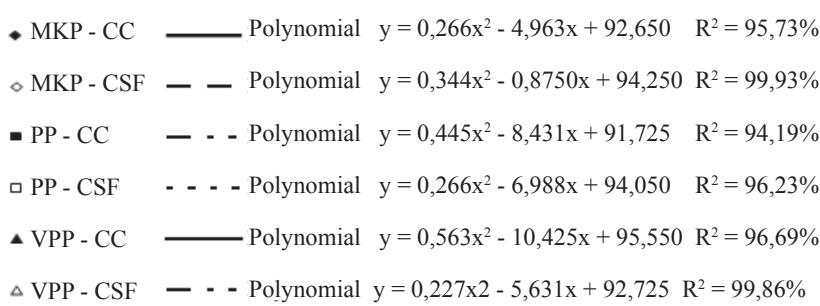

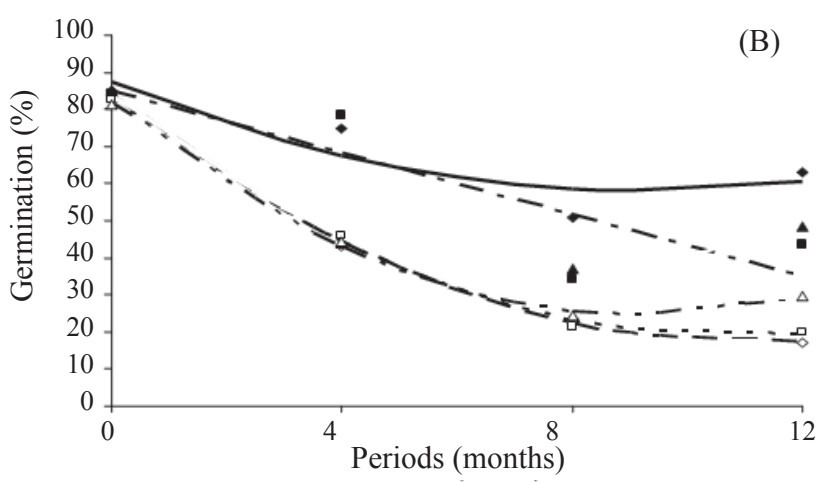

- MKP - CC Polynomial $y=0,344 x^{2}-6,375 x+87,500 R^{2}=80,80 \%$

$\triangle$ MKP - CSF — Polynomial $y=0,539 x^{2}-11,981 x+83,575 R^{2}=99,87 \%$

- PP - CC - - -Polynomial y $=-4,150 x+84,890 \quad R^{2}=73,82 \%$

口 PP - CSF - - - Polynomial $y=0,547 x^{2}-11,863 x+83,050 R^{2}=99,76 \%$

\VPP - CC Polynomial $y=0,820 x^{2}-12,755 x+84,225 R^{2}=99,13 \%$

$\triangle$ VPP - CSF - - Polynomial $y=0,656 x^{2}-12,276 x+81,900 R^{2}=99,84 \%$

Figure 1. Percentage of germination of seeds of the sunflower hybrids Helio 250 (A) and Helio 251 (B) as function of storage periods (0 to 12 months) and storage conditions (cold chamber $=\mathrm{CC}$; conventional storage facilities $=\mathrm{CSF}$; bags of multiwall Kraft paper $=$ MKP; plastic packaging $=$ PP; and vacuum sealed plastic packaging $=$ VPP).

By verifying the curves of response to test of accelerated aging, it is noticeable a decreasing trend of seed germination for all storage conditions and for both hybrids studied (Figure 2), and that the decrease on germination was more accentuated in the environment without temperature control. That event is based on the fact that seed deterioration rate is considerably increased by their exposure to highly adverse levels of temperature and relative humidity. According to the vigor, which was estimated by the accelerated aging test, it was determined that storage under cold chamber conditions is efficient on preserving physiological quality of sunflower seeds as compared to normal environmental conditions, until the end of storage period; and that under such environment, the vigor of sunflower seeds packaged into multiwall Kraft paper bags should be recommended. For the conditions of conventional storage facilities, however, more favorable results on preserving seeds of sunflower were obtained by using packaging of transparent plastic, sealed under vacuum.

Based on the oil content in the seeds of the hybrids studied (Figure 3), although there have not been statistically significant differences among treatments; a trend of reduction on the oil content along storage period was indeed noticed. Similar results were obtained by Balesevic-Tubic et al. (2007), who have not observed significant changes on the content of oil in sunflower seeds stored during of 12 months under either cold chamber conditions or natural storage conditions. It is important to emphasize that lipids oxidation and the increase on content of free fatty acids during the storage period are the main causes of the fast deterioration of seeds of oil-seed plants, as the sunflower seeds (Balesevic-Tubic et al., 2005).

Methyl esters profiles of fatty acids of the sunflower seeds evaluated within this study are presented on Figure 4. Four types of fatty acids were detected in both hybrid seeds, with predominance of the unsaturated fatty acids: linoleic (C18:2) and oleic (C18:1); as well as the saturated fatty acids: palmitic (C16:0) and stearic (C18:0). The fatty acids linoleic and oleic, have totaled $80 \%$ of the total fatty acids verified in all treatment assessed. It was not verified significant difference on the fatty acids profile, which have had a stable behavior during all storage period of sunflower seeds.

The enzymes profiles obtained in seeds of both the sunflower genotypes, have revealed that, for the peroxide 
dismutase (SOD) enzyme (Figure 5) there has been a decrease on its activity starting from T4 ( plastic packaging; under conventional storage); and at the subsequent periods it was not possible to detect the activity of such enzyme on the treatments assessed. Such results corroborate results found by Goel et al. (2003) with cotton seeds, in which reduction on the activity of the SOD enzyme during seed aging were observed.

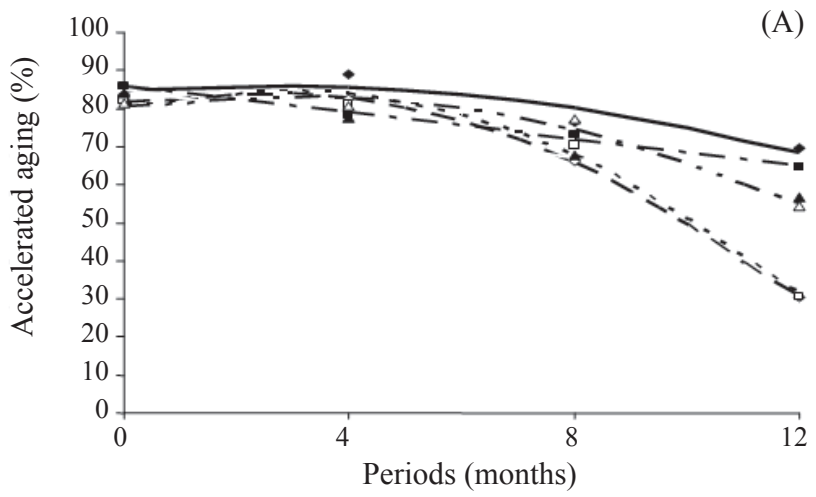

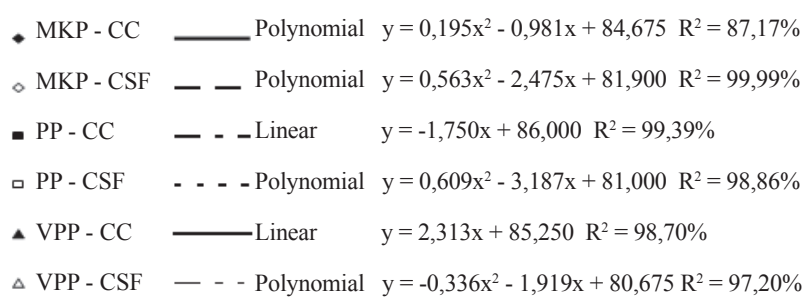

Bailly et al. (1996) have found that the loss of viability of sunflower seeds (that present high content of oil) is associate to the decrease of the activity of the enzyme superoxide dismutase, due to the fact that the seed aging stimulates peroxidation of lipids and the reduction of the activity of peroxide removal enzymes, such as the enzymes peroxidase and superoxide dismutase.

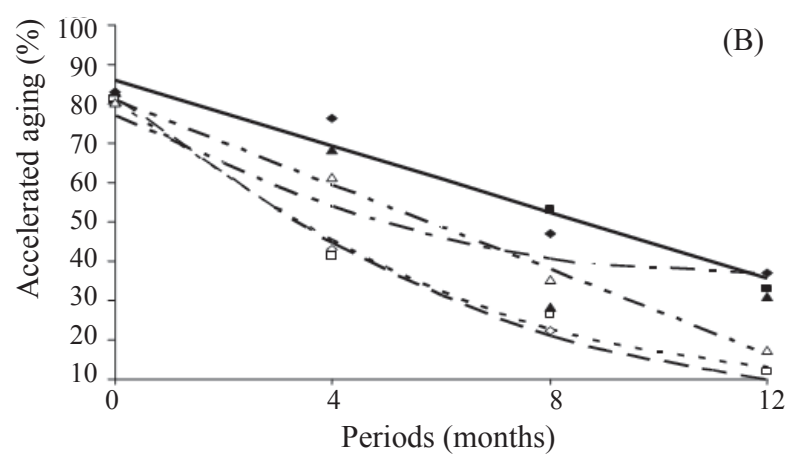

- MKP-CC LLinear $\quad \mathrm{y}=4,188 \mathrm{x}-86,000 \mathrm{R}^{2}=93,76 \%$

$\bullet$ MKP - CSF - - Polynomial y $=0,406 x^{2}-10,825 x+81,450 R^{2}=99,80 \%$

- PP - CC - - -Polynomial $y=0,305 x^{2}-6,969 x+76,875 R^{2}=74,09 \%$

- PP - CSF - - - Polynomial $y=0,398 x^{2}-10,369 x+80,276 R^{2}=98,88 \%$

$\triangle \mathrm{VPP}-\mathrm{CC} \quad$ Linear $\mathrm{y}=4,900 \mathrm{x}+82,150 \mathrm{R}^{2}=86,36 \%$

$\triangle \mathrm{VPP}$ - CSF - - - Linear $\quad \mathrm{y}=-5,375 \mathrm{x}+81,000 \mathrm{R}^{2}=99,50 \%$

Figure 2. Accelerated aging (\%) of seeds of the sunflower hybrids Helio 250 (A) and Helio 251 (B) as function of storage periods ( 0 to 12 months) and storage conditions (cold chamber $=\mathrm{CC}$; conventional storage facilities $=\mathrm{CSF}$; bags of multiwall Kraft paper $=$ MKP; plastic packaging $=$ PP; and vacuum sealed plastic packaging $=$ VPP $)$.
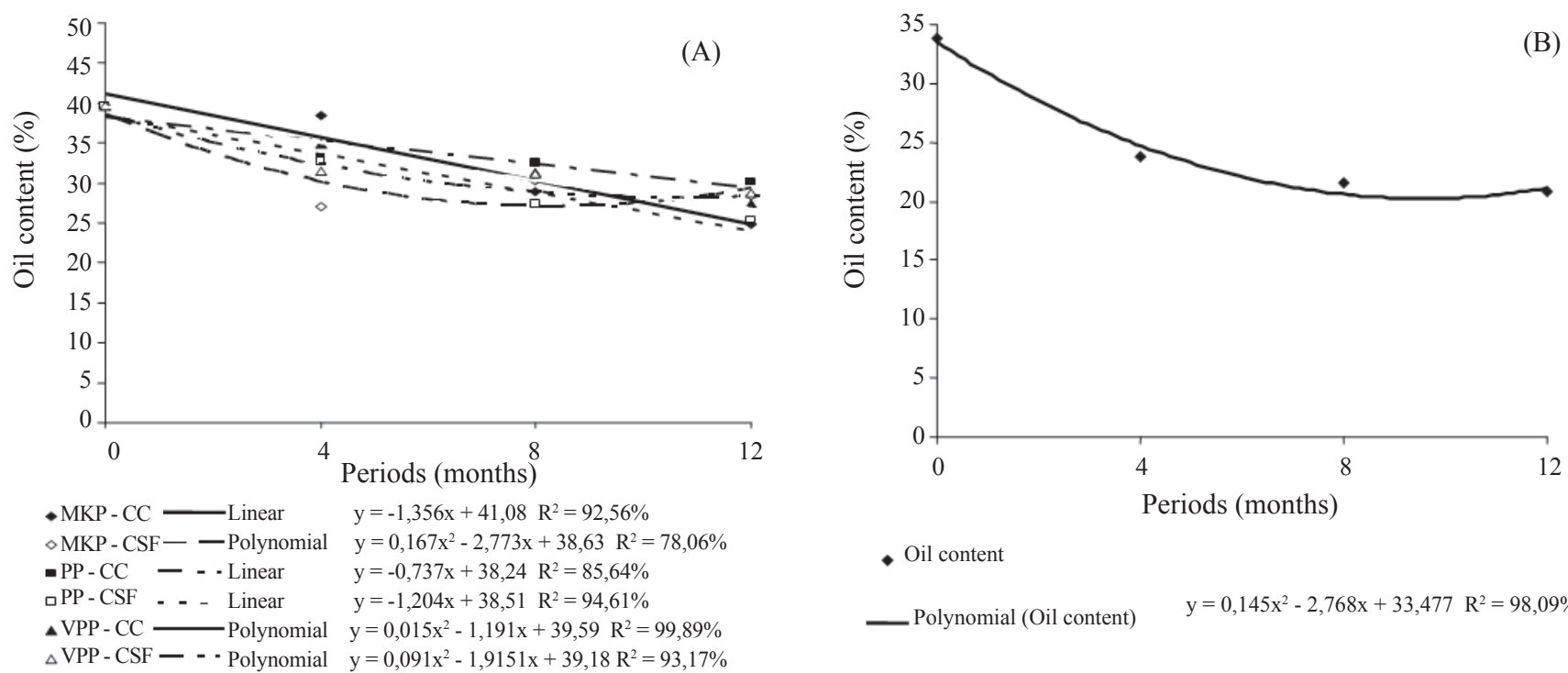

- Oil content

_ Polynomial (Oil content) $\quad \mathrm{y}=0,145 \mathrm{x}^{2}-2,768 \mathrm{x}+33,477 \quad \mathrm{R}^{2}=98,09 \%$

Figure 3. Oil content (\%) in seeds of the sunflower hybrids Helio 250 (A) and Helio 251 (B) as function of storage periods (0 to 12 months) and storage conditions (cold chamber $=\mathrm{CC}$; conventional storage facilities $=\mathrm{CSF}$; bags of multiwall Kraft paper $=$ MKP; plastic packaging $=$ PP; and vacuum sealed plastic packaging $=$ VPP $)$. 

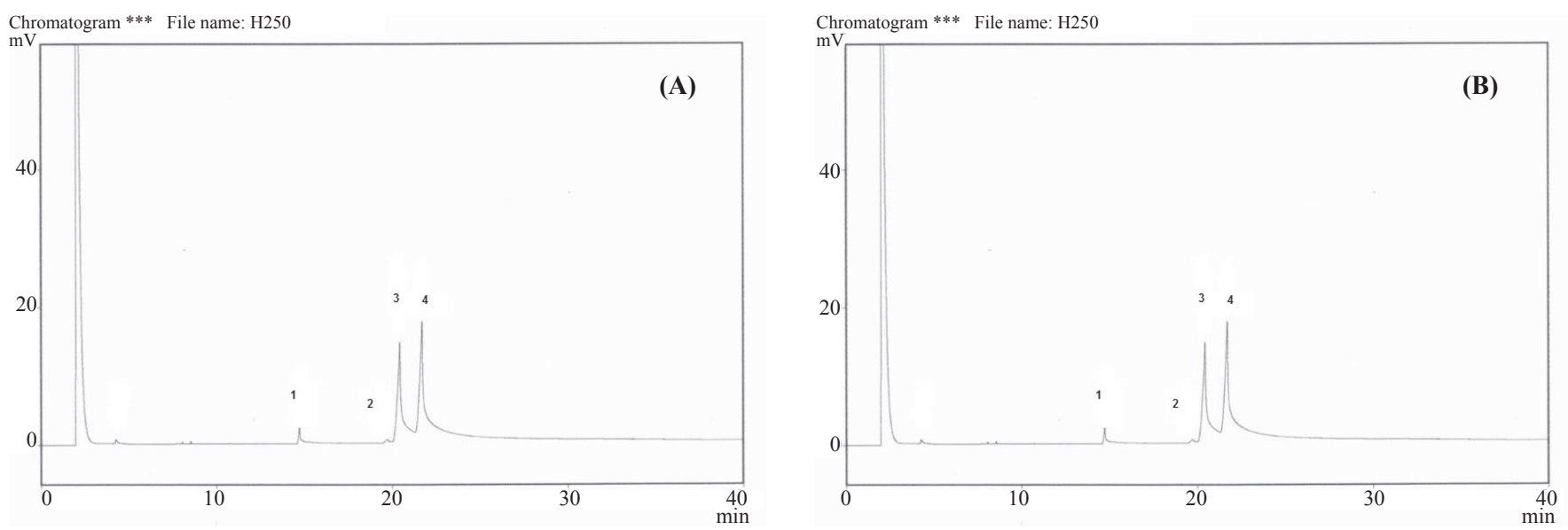

Figure 4. Profile of the methyl esters of fatty acids of sunflower hybrids Helio 250 (A) and Helio 251 (B). 1 - Palmitic acid (C16:0); 2 - Stearic acid (C18:0); 3 - Oleic acid (C18:1 n-9); 4 - linoleic acid (C18:2).
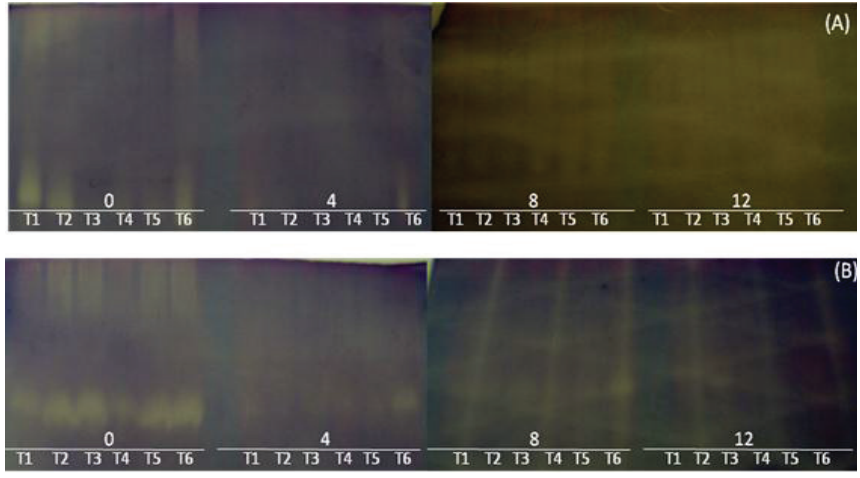

Figure 5. Isoenzymes patterns of sunflower seeds of hybrids Helio 250 (A) and Helio 251 (B) subjected to different storage periods $(0,4,8$ and 12 months) under different packaging and storage conditions (T1 - plastic bag, into cold chamber; $\mathrm{T} 2$ - Kraft paper, into cold chamber; T3 - Vacuum, into cold chamber; T4 - plastic bags, under conventional storage facilities; T5 - Kraft paper, under conventional storage facilities; T6 - vacuum, under conventional storage facilities), which have been revealed for the enzyme superoxide dismutase (SOD).

It was likewise verified that for the enzyme alcohol dehydrogenase (ADH) (Figure 6), there was a decrease on the intensity of the electrophoretic bands with the increase in the storage period, mainly for seeds of hybrid Helio 251, independent of storage environment. It has to be emphasized, however, that in the fourth and eighth month of storage under cold conditions, a higher activity of the ADH enzyme was verified on seeds packaged
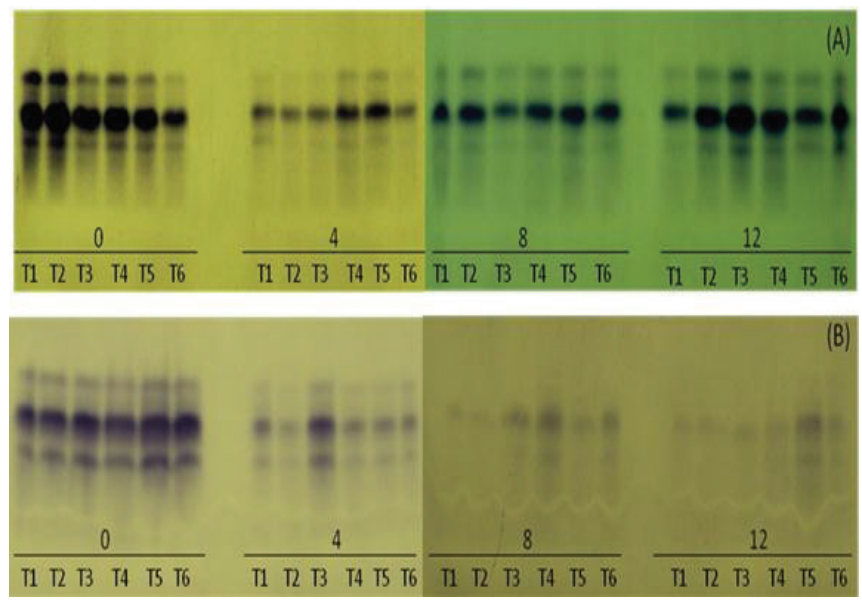

Figure 6. Isoenzymes patterns of sunflower seeds of hybrids Helio 250 (A) and Helio 251 (B) subjected to different storage periods ( $0,4,8$ and 12 months) under different packaging and storage conditions (T1 - plastic bag, into cold chamber; T2 - Kraft paper, into cold chamber; T3 - Vacuum, into cold chamber; T4 plastic bags, under conventional storage facilities; T5 - Kraft paper, under conventional storage facilities; T6 - vacuum, under conventional storage facilities), which have been revealed for the enzyme Alcohol dehydrogenase (ADH).

under vacuum. This behavior was due to the higher activity of the enzyme ADH in seeds packaged under vacuum. Such behavior is a consequence of the reduction of oxygen availability that has caused the activation of the anaerobic pathway of respiration process.

For the enzyme malate dehydrogenase (MDH) (Figure 7), variations on the enzymatic activity that could be associated to reduction of seed physiological quality for both hybrids under 
study were not observed. The degradation and the inactivation of the enzymes, due to changes in their macromolecular structures are the main proposed hypotheses as responsible causes by the seed aging process (Bailly, 2004; Lehner et al., 2008).
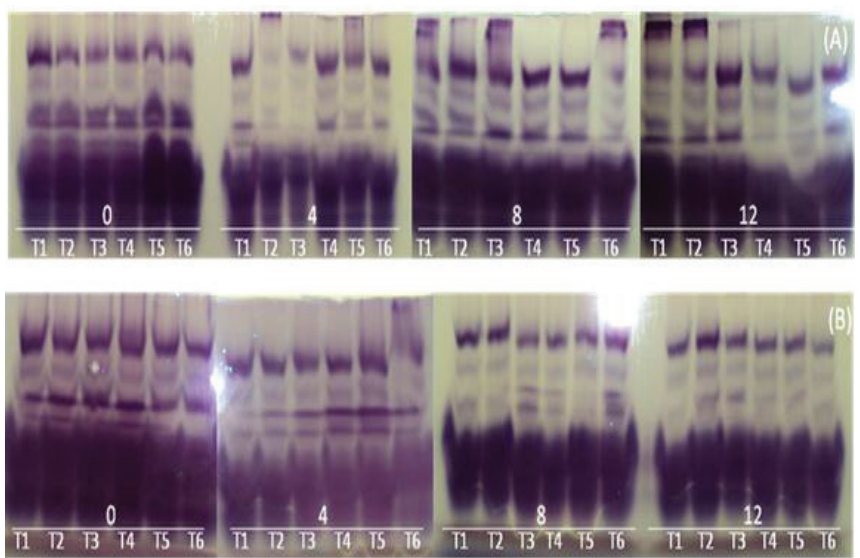

Figure 7. Isoenzymes patterns of sunflower seeds of hybrids Helio 250 (A) and Helio 251 (B) subjected to different storage periods $(0,4,8$ and 12 months) under different packaging and storage conditions ( $\mathrm{T} 1$ - plastic bag, into cold chamber; T2 - Kraft paper, into cold chamber; T3 - Vacuum, into cold chamber; T4 - plastic bags, under conventional storage facilities; T5 - Kraft paper, under conventional storage facilities; T6 - vacuum, under conventional storage facilities), which have been revealed for the enzyme malate dehydrogenase (MDH).

\section{Conclusions}

The storage under cold chamber condition is more efficient on preserving the physiological quality of sunflower seeds; and under such storage condition the packaging into paper bags is more adequate;

The preservation of sunflower seeds under conventional storage facilities within plastic packaging, sealed under vacuum, provides better maintenance of seed physiological quality;

Changes on physiological quality of sunflower seeds stored under different environmental conditions can be detected by analysis of the alcohol dehydrogenase and peroxide dismutase enzymatic systems; what does not occur in relation to the malate dehydrogenase system;

The oil content in seeds of sunflower decreases along time, independent of storage condition; and the oleic and linoleic fatty acids are predominant in the total of oil extracted from sunflower seeds;

There has been no significant difference on the fatty acids profile of seeds of sunflower stored under the different environmental conditions.

\section{Acnowledgements}

The authors would like to thank to "Fapemig" by the scholarship granted; to "CNPq"; and to "CAPES" by the financial support provided to the research work.

\section{References}

ALFENAS, A.C. Eletroforese de isoenzimas e proteinas afins: fundamentos e aplicações em plantas e microorganismos. Viçosa, MG: UFV, 1998. 574p.

BAIlly, C.; BENAMAR, A.; CORBINEAU, F.; CÔME, D. Changes in malondialdehyde contend and in superoxide dismutase, catalase and glutathione reductase activities in sunflower seeds as related to deterioration during accelerated aging. Physiologia Plantarum, v.97, n.1, p.104-110, 1996 http://www.scielo.br/scielo.php?script=sci_nlinks\&ref=000065\&pid=S0101 $3122201000010001000004 \& \operatorname{lng}=$ en

BAILLY, C. Active oxygen species and antioxidants in seed biology Seed Science Research, v.14, p.93-107, 2004. http://journals.cambridge. org/download.php?file $=\% 2$ fssr\%2fssr14_02\%2fs0960258504000108a. pdf\&code $=302486397 \mathrm{a} 23 \mathrm{~b} 36179829 \mathrm{c} 68 \mathrm{c} 457666 \mathrm{~d}$

BAILLY, C.; BOGATEK-LESZCZYNSKA, R.; CÔME, D.; CORBINEAU, F. Changes in activities of antioxidant enzymes and lipoxygenase during growth of sunflower seedlings from seeds of different vigour. Seed Science Research, v.12, n.1, p.47-55, 2002. http://journals.cambridge.org/action/ displayabstract? frompage $=$ online $\&$ aid $=704312$

BALESEVIC-TUBIC, S.; MALENÈIC, D.; TATIC, M.; MILADINOVIC, J. Influence of aging process on biochemical changes in sunflower seed. Helia, v.28, n.42, p.107-114, 2005. http://www.doiserbia.nb.rs/img/doi/10181806/2005/1018-18060542107b.pdf.

BALESEVIC-TUBIC, S.; TATIC, M.; MILADINOVIC, J.; PUCAREVIĆ, $\mathrm{M}$. Changes of fatty acids content and vigor of sunflower seed during natural aging. Helia, v.30, n.47, p.61-68, 2007. http://www.doiserbia.nb.rs/img/doi/10181806/2007/1018-18060747061B.pdf

BRASIL. Ministério da Agricultura, Pecuária e Abastecimento. Regras para Análises de Sementes. Ministério da Agricultura, Pecuária e Abastecimento. Secretaria de Defesa Agropecuária. Brasília, DF: MAPA/ACS, 2009. 395p. http://www.bs.cca.ufsc.br/publicacoes/regras\%20analise $\% 20$ sementes.pdf

CAMARGO, R.; CARVALHO, M.L.M. Armazenamento a vácuo de semente de milho doce. Revista Brasileira de Sementes, v.30, n.1, p.131-139, 2008. http://dx.doi.org/10.1590/S0101-31222008000100017.

CARVALHO, C.G.P. (Org.) Informes de avaliação de genótipos de girassol, 2002/2003. Londrina: Embrapa Soja, 2003. 97p. (Embrapa Soja. Documentos, 226).

CAVASIN, P. A cultura do girassol. Guaíba: Agropecuária, 2001. 69p.

GOEL, A.; GOEL, A.K.; SHEORAN, I.S. Changes in oxidative stress enzymes during artificial ageing in cotton (Gossypium hirsutum L.) seeds. Journal of Plant Physiology, v.160, p.1093-1100, 2003. http:// www. sciencedirect.com///s0176161704704988

GRISI, P.U.; SANTOS, C.M. Influência do armazenamento, na germinação 
das sementes de girassol. Horizonte Cientifico, v.1, n.7, p.14-17, 2007. www. seer.ufu.br/index.php/horizontecientifico/article/.../2895

KOUTROUBAS, S.D.; PAPAKOSTA, D.K.; DOITSINIS, A. Water requirements for castor oil crop (Ricinus communis L.) in a Mediterranean climate. Crop Science, v.40, n.1, p.33-41, 2000. http://onlinelibrary.wiley. com/doi/10.1046/j.1439-037x.2000.00357.x/pdf

LEHNER, A.; CORBINEAU, F.; BAILly, C. Changes in lipid status and glass properties in cotyledons of developing sunflower seeds. Plant Cell Physiology, v.47, p.818-828, 2006. http://www.ncbi.nlm.nih.gov/ pubmed/16707505

LEHNER, A.; MAMADOU, N.; POElS, P.; CÔME, D.; BAILly, C.; CORBINEAU, F. Changes in soluble carbohydrates, lipid peroxidation and antioxidant enzyme activities in the embryo during ageing in wheat grains. Journal Cereal Science, v.47, p.555-565, 2008. http://dx.doi.org/10.1016/j.jcs.2007.06.017
SCHMIDT, L. Tropical forest seed. Dinamarca: DFSC, 2007. 421p.

SCHWEMBER, A.; BRADFORD, K. J. Quantitative trait loci associated with longevity of lettuce seeds under conventional and controlled deterioration storage conditions. Journal of Experimental Botany, v.61, n.15, p.4423-4436, 2010. http://jxb.oxfordjournals.org/content/early/2010/08/06/jxb.erq248.full

TONIN, G.A.; PEREZ, S.C.J.G.A. Qualidade fisiológica de sementes de Ocotea porosa (Nees et Martius ex. Nees) após diferentes condições de armazenamento e semeadura. Revista Brasileira de Sementes, v.28, n.2, p.2633, 2006. http://dx.doi.org/10.1590/S0101-31222006000200004

WALTERS, C.T.; BALLESTEROS, D.; VERTUCCI, V. Structural mechanics of seed deterioration: Standing the test of time. Plant Science, v.179, p.565573, 2010. http://dx.doi.org/10.1016/j.plantsci.2010.06.016 